\title{
Effect of different Bacillus thuringiensis strains on the longevity of Africanized honey bee
}

\author{
Efeito de diferentes linhagens de Bacillus thuringiensis na \\ longevidade de Apis mellifera $\mathrm{L}$ africanizada
}

\author{
Gabriela Libardoni ${ }^{1}$; Alfredo de Gouvea ${ }^{2}$; Fabiana Martins Costa-Maia ${ }^{3}$; Everton \\ Ricardi Lozano ${ }^{4}$; Patricia Franchi de Freitas ${ }^{4}$; Fernanda Caroline Colombo ${ }^{5}$; \\ Fernanda Raulino ${ }^{1}$; Rodrigo Mendes Antunes Maciel ${ }^{1}$; Michele Potrich ${ }^{4 *}$
}

\begin{abstract}
The aim of this study was to assess the effects of three strains of Bacillus thuringiensis (Bt) on the longevity of workers of Africanized honey bee. Solutions at a concentration of $3.0 \times 10^{8}$ spores $\mathrm{mL}^{-1}$ (dosage) were prepared for each strain of Bt (IPS 82, BR 81, and BR 147). Three bioassays were performed as follows: spraying on the bees, contact with the sprayed surface, and candy paste incorporated with Bt. The bees of the Bt bioassay were submitted to histological analysis of the mesenteron. The longevity of workers was assessed from one to 120 hours using different ranges. It was found that the bees that were exposed to the strain of Bt IPS 82, in the spraying test, exhibited a reduced longevity. In the contact test, the BR 147 strain reduced the longevity of the bees. In the food test, in turn, the three studied strains reduced the longevity of the bees as follows: Bt IPS 82: 64.5 hours; Bt BR 81: 64.5 hours; and Bt BR 147: 60.0 hours. The Bt BR 81 strain was considered the most selective of the evaluated strains on Apis mellifera, reducing the longevity of this bee only when it came into contact by the method of ingestion. Key words: Africanized honey bee. Entomopathogenic bacteria. Selectivity.
\end{abstract}

\section{Resumo}

O objetivo deste trabalho foi avaliar o efeito de três linhagens de Bacillus thuringiensis (Bt) sobre a longevidade de operárias de Apis mellifera africanizadas. Para isso foram preparadas soluções, na concentração de $3.0 \times 10^{8}$ esporos $\mathrm{mL}^{-1}$ (dosagem comercial), para cada linhagem de Bt (IPS 82, BR 81 e BR 147). Foram realizados três bioensaios: pulverização sobre as abelhas, contato com superfície pulverizada e pasta Cândi incorporada com Bt. As abelhas do bioensaio de Bt incorporado à alimentação foram submetidos à análise histológica do mesêntero. A longevidade das operárias foi avaliada de uma até 120 horas utilizando diferentes intervalos. Verificou-se que no teste de pulverização, as abelhas que entraram em contato com a linhagem de Bt IPS 82 apresentaram redução de longevidade. No teste de contato, a linhagem BR 147 reduziu a longevidade das abelhas. No teste de alimentação as três

\footnotetext{
${ }^{1}$ Discentes de Mestrado, Programa de Pós-Graduação em Zootecnia, PPGZO, Universidade Tecnológica Federal do Paraná, UTFPR, Campus Dois Vizinhos. Dois Vizinhos, PR, Brasil. E-mail: gabbylibardoni@hotmail.com; fernanda_raulino@live.com; digoantuness@gmail.com

2 Prof. Dr., Coordenação de Agronomia, UTFPR, Campus Dois Vizinhos, Dois Vizinhos, PR, Brasil. E-mail: alfredo@utfpr.edu.br

${ }^{3}$ Prof $^{\mathrm{a}}$ Dr $^{\mathrm{a}}$, Coordenação de Zootecnia, UTFPR, Campus Dois Vizinhos, Dois Vizinhos, PR, Brasil. E-mail: fabianamcosta@utfpr. edu.br

${ }^{4}$ Profs. Drs., Coordenação de Ciências Biológicas, UTFPR, Campus Dois Vizinhos, Dois Vizinhos, PR, Brasil. E-mail: evertonlricardi@utfpr.edu.br; patriciafreitas@utfpr.edu.br; michelepotrich@utfpr.edu.br

5 Discente de Mestrado, Programa de Pós-Graduação em Agroecossistemas, PPGSIS, UTFPR, Campus Dois Vizinhos, Dois Vizinhos, PR, Brasil. E-mail: fer.colombo@hotmail.com

* Author for correspondence
} 
linhagens estudadas reduziram a longevidade das abelhas Bt IPS 82: 64,5 horas; Bt BR 81: 64,5 horas e Bt BR 147: 60,0 horas. A linhagen Bt BR 81 foi considerada a mais seletiva, dentre as avaliadas, reduzindo a longevidade da abelha $A$. mellifera apenas quando ingerida.

Palavras-chave: Abelha africanizada. Bactéria entomopatogênica. Seletividade.

\section{Introduction}

Bacillus thuringiensis Berliner (Bt) is one of several groups of entomopathogenic bacteria used in biological control. This bacterium is used as bioinsecticide for agricultural pest control, particularly caterpillars, in crops of tomatoes, cotton, citrus, manioc, soybeans, wheat and corn (ANGELO et al., 2010; BRAVO et al., 2011). Entomopathogenic microorganisms, such as bacteria, need to be tested before they are applied in the field since, apart from insect pests, they can affect non-target organisms such as pollinators (GALLO et al., 2002). One of these pollinators is the Africanized bee, Apis mellifera L. (Hymenoptera: Apidae).

Apis mellifera is a bee that is highly regarded as a pollinator of commercial crops (STRAUB et al., 2016). There is interest in maintaining these colonies, especially in agriculture, because they boost production, leading to high productivity and improved seed and fruit quality, besides producing honey, Royal Jelly, and propolis (VIUDA et al., 2008; RANGBERG et al., 2012; MARINI et al., 2015). Moreover, the absence of pollinators results in the low production of fruit and a lack of standardization in terms of form, appearance, taste, size and shape, which can reduce revenue and profit for producers (COBRA et al., 2015).

Bacillus thuringiensis var. kurstaki (commercial name Dipel ${ }^{\circledR} \mathrm{PM}$ ) proved toxic to adults of A. mellifera in the laboratory when sprayed on the workers and when added to the candy paste (BRIGHENTI et al., 2007). However, $B$. thuringiensis sub sp. kurstaki (Btk) when aerially sprayed does not affect the performance of the brood of A. mellifera bee colonies or interfere in the health of the colony and the behavior of bees. In addition, spray application did not change the behavior of the colonies, compared to before, during and after spraying the brood (LEZ et al., 2014).

D'Urso et al. (2017) found that B. thuringiensis var. aizawai and kurstaki (strain GC 91) (at the dosage recommended by the manufacturer) did not interfere with the survival of $A$. mellifera and did not cause morphological changes in the midgut of the worker bees.

However, with the advent of new products based on $B$. thuringiensis and the use of different strains on insect pests, selectivity must be constantly reviewed to verify the safety of these products for non-target organisms. The aim of this study was to assess the effects of three strains of Bacillus thuringiensis (Bt) on longevity of workers of Africanized honey bee Apis mellifera.

\section{Materials and Methods}

This study was conducted at the Universidade Tecnológica Federal do Paraná, Campus Dois Vizinhos (UTFPR-DV), at the Laboratory of Biological Control I and II and in the Apiculture Teaching and Research Unit (UNEPE-Beekeeping).

\section{Obtaining A. mellifera and B. thuringiensis}

Africanized honey bee: The frames containing 19-day-old worker bee larvae were obtained from colonies at the apiary at the Teaching and Research Unit (UNEPE) - Apiculture. The frames were transported to the Laboratory of Biological Control. At the laboratory, the frames were wrapped in Kraft paper bags, sealed, perforated, and kept in a heated BOD-type incubator $\left(34 \pm 2{ }^{\circ} \mathrm{C}, \mathrm{RH} 60 \pm 5 \%\right)$ for two days. The conditions ensured the even emergence of workers for use in bioassays by simulating the environment of the colony. Apis mellifera bees used 
in the bioassays were fed with candy paste made by mixing $50 \mathrm{~g}$ icing sugar with $10 \mathrm{~mL}$ of pure honey until it formed a homogeneous mass.

Bacillus thuringiensis: Three strains of this bacterium were used, namely IPS 82, BR 81 , and BR 147. These bacteria were obtained from the entomopathogenic collection of the Laboratory of Genetics and Taxonomy of Microorganisms at the Universidade Estadual de Londrina - UEL, identified by the presence of Cry proteins toxic to species of the orders Coleoptera and Diptera. These strains were multiplied and quantified until we obtained the commercial concentration of $3.0 \times 10^{8}$ spores $\mathrm{mL}^{-1}$.

\section{Bioassay 1: Spraying of B. thuringiensis on A. mellifera}

The newly emerged $A$. mellifera workers were anesthetized with $\mathrm{CO}_{2}$ for $120 \mathrm{~s}$, placed in Petri dishes and then sprayed with the treatments using a Pneumatic Sagyma ${ }^{\circledR}$ airbrush coupled to a Fanem ${ }^{\circledR}$ constant pressure pump at $1.2 \mathrm{kgf} \mathrm{cm}^{-1}$. Ten worker bees were then transferred to plastic containers $(100 \mathrm{~mm} \times 120 \mathrm{~mm})$, each group of 10 bees was considered a repetition, with a total of six repetitions per treatment. The containers were sealed with voile fabric and food, consisting of candy paste and a piece of cotton wool soaked in distilled water, was placed on top of the fabric.

The control treatment was the spraying of sterile deionized water spray, and treatments based on $B$. thuringiensis were applied at a concentration of 3.0 $\times 10^{8}$ spores $\mathrm{mL}^{-1}$. The experiments were conducted in a BOD-type chamber $\left(34 \pm 2{ }^{\circ} \mathrm{C}, \mathrm{RH}\right.$ of $60 \pm$ $5 \%)$ and the mortality of the worker bees evaluated at $1 ; 2 ; 3 ; 4 ; 5 ; 6 ; 9 ; 12 ; 15 ; 18 ; 21 ; 24 ; 30 ; 36$; $42 ; 48 ; 60 ; 72$; and $96 \mathrm{~h}$ after spraying the control agents methodology adapted from (BAPTISTA et al., 2009).
Bioassay 2: Contact of A. mellifera with surface sprayed with $B$. thuringiensis

Glass Petri dishes $(15 \mathrm{~cm}$ diameter $\times 1.5 \mathrm{~cm}$ height) were each sprayed with $290 \mu \mathrm{L}$ of solution containing one of the strains of $B$. thuringiensis. The calculation of volume solution was based on the area of the dish on which the solution is sprayed. A Pneumatic Sagyma ${ }^{\circledR}$ airbrush coupled to a Fanem ${ }^{\circledR}$ with constant pressure pump $\left(1.2 \mathrm{kgf} \mathrm{cm}^{-1}\right)$ was used. Subsequently, these dishes were arranged in a horizontal laminar flow cabinet until the water was completely evaporated. The dishes were then placed in such a way that the gap almost fitted together, to allow room for airflow methodology adapted from (CARVALHO et al., 2009).

Ten A. mellifera workers, previously anesthetized with $\mathrm{CO}_{2}$ for $120 \mathrm{~s}$, were placed inside each dish. Eache dish represented a repetition, with a total of six repetitions per treatment. The control treatment consisted of the spraying of sterile deionized water. After $2 \mathrm{~h}$ of contact with the products, the bees were transferred to plastic containers, where they were provided with candy paste and cotton soaked in water. The experimental conditions, evaluated parameters, and data analysis are the same as those described for Bioassay 1.

\section{Bioassay 3: Candy paste containing B. thuringiensis}

Ten recently emerged $A$. mellifera workers were anesthetized with $\mathrm{CO}_{2}$ for $120 \mathrm{~s}$ and packed individually in a flat-bottomed glass tube $(2.5 \times$ $8.5 \mathrm{~cm})$. The tube was sealed with voile fabric, on which was placed a piece of cotton soaked in distilled water. The food was candy paste containing $B$. thuringiensis. The dose of B. thuringiensis was calculated according to the recommended dosage for use in the field. Each group of ten tubes represented a repetition, with a total of six repetitions per treatment. The control bees were supplied with pure candy paste. The experimental conditions, evaluated parameters, and data analysis are the same as those described for Bioassay 1. 
Eight workers per treatment group, after its death, were selected for mesenteron examination. For removal of the mesenteron, the body of each bee was divided into fragments to facilitate preparation and ensure the quality of the samples. These samples were fixed in Bouin's solution (250 $\mathrm{mL}$ formaldehyde $40 \%+50 \mathrm{~mL}$ glacial acetic acid $\mathrm{PA}+750 \mathrm{~mL}$ saturated solution of picric acid $1.4 \%$ ) for $4 \mathrm{~h}$, washed in $70 \%$ alcohol $(3 \times 15 \mathrm{~min})$ and stored in alcohol $70 \%$ until processing.

The samples stored in $70 \%$ alcohol were dehydrated by immersion in serial alcohol concentrations, according to an adapted histological method (80\% alcohol: $10 \mathrm{~min}$; 90\% alcohol: $10 \mathrm{~min}$; 95\% alcohol: $10 \mathrm{~min}$; 98\% alcohol: $10 \mathrm{~min} ; 100 \%$ alcohol: $2 \times 30 \mathrm{~min}$ ), and subsequently cleared by immersion in xylol (alcohol/xylol 1:1 for $30 \mathrm{~min}$; xylol I: $30 \mathrm{~min}$; xylol II: $30 \mathrm{~min}$ ). The next step was embedding in paraffin wax (xylol/paraffin wax 1:1 for 30 min; paraffin wax I: 180 min; paraffin wax II: 15 min) and blocking in paraffin wax (paraffin wax/ beeswax 4:1).

The blocked material was sectioned using a manual rotary microtome into pieces 2 to $7 \mu \mathrm{m}$ thick, mounted on frosted tip slides $(3 \times 10 \mathrm{~cm})$ coated with albumin solution, and placed on a hot plate to distend the cuts.

The sections were stained using hematoxylin/ eosin (H\&E), by take off paraffin (xylol I: $10 \mathrm{~min}$; xylol II: $10 \mathrm{~min}$; 100\% alcohol I: $5 \mathrm{~min} ; 100 \%$ alcohol II: $5 \mathrm{~min}$ ) and rehydration (alcohol 90\%: 5 min; 80\% alcohol: 5 min; running distilled water: $2 \mathrm{~min}$ ). For staining, the sections were immersed in hematoxylin (40 s), washed under running water (10 min), immersed in eosin (10 s), and again washed in running distilled water (10 s). Sections were dried in an oven at $35{ }^{\circ} \mathrm{C}$ for two days, after which they were mounted in Canada Balsam and covered with glass coverslips $(2.3 \times 3.6 \mathrm{~cm})$ ready for microscopic examination.

Prepared sections were examined using a binocular biological microscope (Zeiss Primo Star) $(40 \times$ lens $)$, with a digital camera to capture images. We compared tissue fromthe digestive system of the $A$. mellifera worker bees fed with candy paste containing $B$. thuringiensis with tissue from $A$. mellifera worker bees fed with pure candy paste.

\section{Statistical analyses}

The longevity data for A. mellifera workers from the three bioassays were submitted to the Shapiro-Wilk normality test, followed by analysis of variance (ANOVA). The average values were compared using the Duncan test at 5\% probability and Assistat ${ }^{\circledR}$ software (SILVA; AZEVEDO, 2002).

\section{Results}

In the spraying bioassay of $B$. thuringiensis on A. mellifera (Bioassay 1), it was observed that only strain IPS 82 caused a reduction in longevity $(88.7 \mathrm{~h})$ when compared to the control $(104.7 \mathrm{~h})$. The other strains, BR 81 and BR 147 did not cause changes in the longevity of $A$. mellifera worker bees (Table 1).

The workers from the control treatment and from the BR 147 had a survival of $51.7 \%$ by the end of 120-h experiment; worker bees from BR 81 (43.4\% survival) did not differ from the controls $(51.7 \%$ survival) after $120 \mathrm{~h}$. After $96 \mathrm{~h}$, worker bees from the IPS 82 treatment group showed 100\% mortality, differing from the other treatments (Table 1). 
Table 1. Average longevity (h) and survival (\%) $\pm \mathrm{SE}$ of worker bees of the Africanized honey bee, A. mellifera, after being subjected to three bioassays with different strains of $B$. thuringiensis (Temperature $34 \pm 2{ }^{\circ} \mathrm{C}, \mathrm{RH} 60 \pm 5 \%$ ).

\begin{tabular}{|c|c|c|c|}
\hline Bioassay & Treatment & Average longevity (h) & $\begin{array}{l}\text { Survival after } 120 \mathrm{~h} \\
(\%)\end{array}$ \\
\hline \multirow{4}{*}{ Bioassay 1: Spraying } & Control & $104.7 \pm 2.99 \mathrm{a}$ & $51.7 \pm 0.77 \mathrm{a}$ \\
\hline & Bt 1 (IPS 82) & $88.7 \pm 2.66 b$ & $0 \pm 1.84 \mathrm{~b}$ \\
\hline & Bt 2 (BR 81) & $102.5 \pm 2.57 \mathrm{a}$ & $43.3 \pm 0.80 \mathrm{a}$ \\
\hline & Bt 3 (BR 147) & $105.6 \pm 2.70 \mathrm{a}$ & $51.7 \pm 0.79 \mathrm{a}$ \\
\hline \multirow[t]{2}{*}{$p$ value } & & $p<0.01$ & \\
\hline & Control & $118.4 \pm 0.78 \mathrm{a}$ & $93.3 \pm 0.12 \mathrm{a}$ \\
\hline \multirow{3}{*}{ Bioassay 2: Contact } & Bt 1 (IPS 82) & $111.6 \pm 3.30 \mathrm{a}$ & $88.3 \pm 0.08 \mathrm{a}$ \\
\hline & Bt 2 (BR 81) & $117.8 \pm 1.79 \mathrm{a}$ & $96.7 \pm 0.40 \mathrm{a}$ \\
\hline & Bt 3 (BR 147) & $101.2 \pm 4.19 \mathrm{~b}$ & $63.3 \pm 0.35 b$ \\
\hline \multirow[t]{2}{*}{$p$ value } & & $p<0.01$ & \\
\hline & Control & $90.5 \pm 4.98 \mathrm{a}$ & $52.0 \pm 0.24 \mathrm{a}$ \\
\hline \multirow{3}{*}{$\begin{array}{l}\text { Bioassay 3: Candy paste } \\
\text { incorporated }\end{array}$} & Bt 1 (IPS 82) & $64.5 \pm 4.41 \mathrm{~b}$ & $10.0 \pm 0.50 \mathrm{~b}$ \\
\hline & Bt 2 (BR 81) & $64.5 \pm 5.41 \mathrm{~b}$ & $18.0 \pm 0.36 \mathrm{~b}$ \\
\hline & Bt 3 (BR 147) & $60.0 \pm 3.72 b$ & $6.0 \pm 0.52 b$ \\
\hline$p$ value & & $p<0.01$ & $p<0.05$ \\
\hline
\end{tabular}

Different letters indicate significant differences between averages of treatments, according to the Duncan test at $95 \%$ level of credibility. SE: Standard Error.

In Bioassay 2, when A. mellifera bees were in contact with surface sprayed with Bt, only strain BR 147 caused a reduction in longevity of worker bees of $A$. mellifera (101.2 h) compared to the controls (118.4 h). The other strains (IPS 82: $111.6 \mathrm{~h}$ and BR 81: $117.8 \mathrm{~h}$ ) did not present differences in the longevity of the workers bees. At the end of the 120h experiment, $63.3 \%$ of the $A$. mellifera worker bees were alive with strain BR 147, differing from strains IPS $82(88.3 \%)$ and BR 81 (96.7\%), and the control (93.3\%) (Table 1).

All the investigated strains of B. thuringiensis, when incorporated into the food of $A$. mellifera (Bioassay 3), reduced the longevity of the workers (IPS 82: $64.5 \mathrm{~h}$; BR 81: $64.5 \mathrm{~h}$ and BR 147: $60 \mathrm{~h}$ ) in relation to the controls $-90.5 \mathrm{~h}$ (Table 1). All three strains investigated reduced the survival of the worker bees. After 120 h, only $10 \%$ of the workers were alive with strain IPS 82 , while $18 \%$ were alive with BR $81,6 \%$ with BR 147 and $52 \%$ in the controls (Table 1).

The histology of the mesenteron of the workers of $A$. mellifera fed with candy and the three strains of $B$. thuringiensis exhibited disintegrated midgut with shapeless cells in comparison to the cells of the mesentera of workers fed with pure candy paste (Figures 1A, B, C and D). The overall cell organization, in the form of crypts, is shown in Figure 1A, while in Figures $1 \mathrm{~B}, \mathrm{C}$, and $\mathrm{D}$ this organization is not observable. 
Figure 1. Photomicrograph of the midgut of Apis mellifera (binocular biological microscope, Zeiss Primo Star, with a digital camera to capture images; 40× magnification). Worker bees fed with: A) Pure candy paste; B) Candy paste + Bt 1 - IPS 82, C) Candy paste + Bt 2 - BR 81, D) Candy paste + Bt 3 - BR 147. e = Epithelial linning; c = Cavity of the midgut.
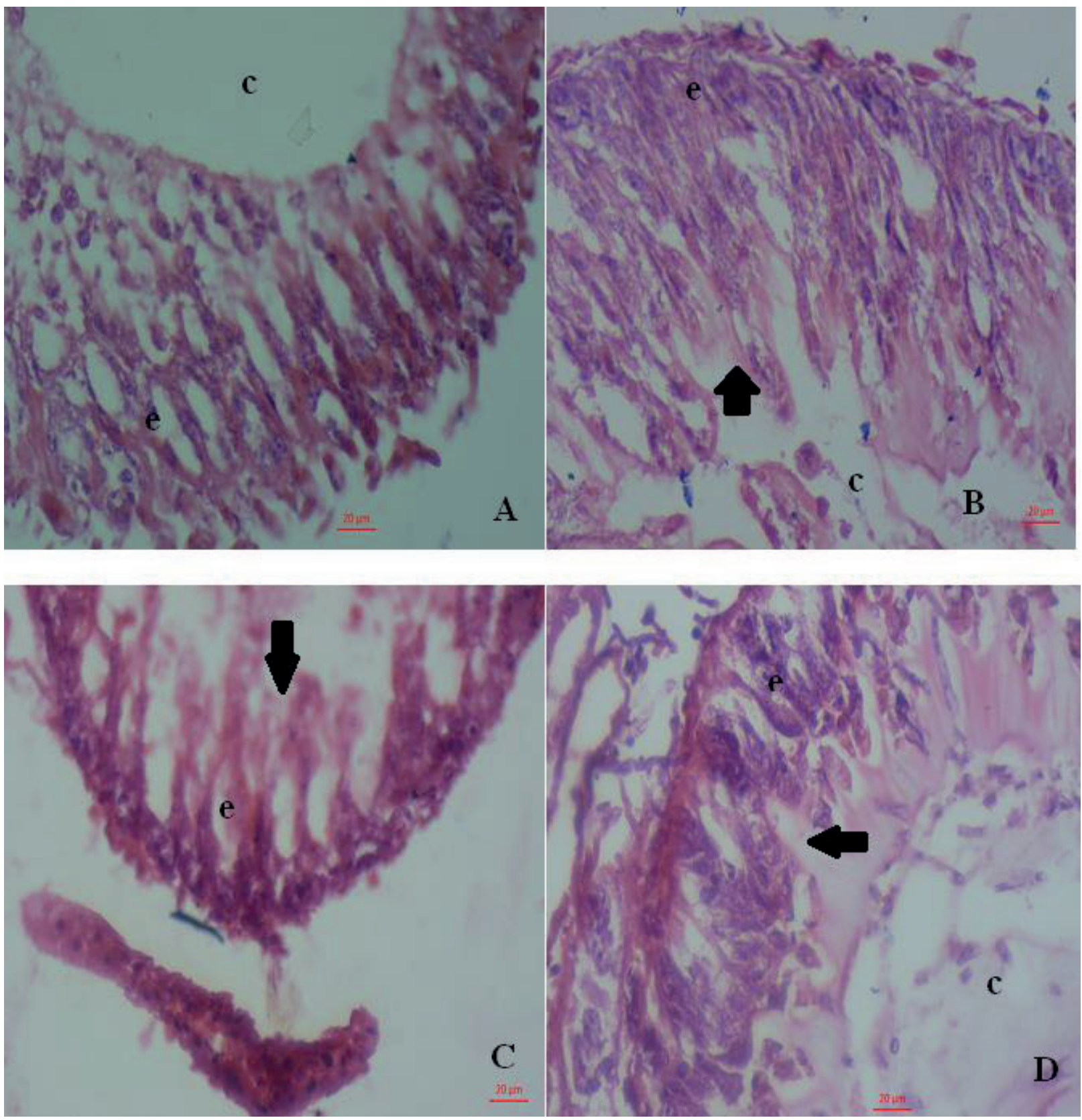

\section{Discussion}

The bioassays "Spraying of $B$. thuringiensis on A. mellifera" (Bioassay 1) and "Contact of $A$. mellifera with surface sprayed with $B$. thuringiensis (Bioassay 2) did not affect the longevity of $A$. mellifera worker bees as much as when $\mathrm{Bt}$ was incorporated into the candy paste (Bioassay 3 ). This occurs because $B$. thuringiensis acts when ingested through the crystals that this bacterium produces. Consequently, when bees are fed with candy paste containing strains of bacteria, their longevity is reduced. 
However, some strains, such as IPS 82 (used in this study), may reduce the longevity of $A$. mellifera workers. This was also observed when $B$. thuringiensis var. kurstaki (commercial name Dipe ${ }^{\circledR}$ $\mathrm{PM}$ - concentration of $0.5 \mathrm{~g} 100 \mathrm{~mL}^{-1}$ - commercial dosage) sprayed onto the adult workers caused significant mortality in $52.4 \%$ of the bees by the end of a 96-h experiment (BRIGHENTI et al., 2007).

In the bioassay Contact of $A$. mellifera with surface sprayed with $B$. thuringiensis, the $B$. thuringiensis strain BR 147 reduced the longevity of the worker bees. Despite the lack of studies on the effect of contact of $A$. mellifera with the bacteria $B$. thuringiensis, in this study one of the strains investigated had a negative effect. Although B. thuringiensis does not act by contact, only by ingestion, contamination may have occurred because social insects, including the young $A$. mellifera bees, exhibit a hygiene habit in which one bee clears the integument from another bee. This can cause them to ingest bacterial spores from their body or from other worker bees, causing changes (BRIGHENTI et al., 2007; TRIPLEHORN; JOHNSON, 2011) and leading to mortality shortly after spraying and/or contact.

Sub-doses of $B$. thuringiensis var. kurstaki, strain HD-1, in Trichogramma pretiosum (Hymenoptera: Trichogrammatidae), negatively influenced the biology of this parasitoid, reducing the percentage and the capabilities of parasitism (BORTOLI et al., 2012). The same occurred with Telenomus remus (Hymenoptera: Platygastridae) sprayed with $B$. thuringiensis (commercial product Dipel ${ }^{\circledR}$ PM) (SILVA et al., 2013).

In the bioassay of food, with candy paste containing $B$. thuringiensis, the three strains caused a reduction in the longevity of the bees. It is believed that this reduction occurred due the mode of action of $B$. thuringiensis by ingestion. It features crystals as the active component, and in the digestive tract of the insect, the crystal produced by the bacterium is in an ideal condition (alkaline $\mathrm{pH}$ ) to be dissolved and absorbed, transforming itself into a toxic substance (60-65 kDa fragments). The epithelial cells of the intestinal villi of the insect recognize the specific receptors that trigger the formation of pores in the membrane of the epithelium, causing extravasation of the digestive liquid, destruction of microvilli membranes, development or overgrowth of epithelial cells, vacuolation of the cytoplasm, and rupture or dissolution of the plasma membrane, leading to paralysis and death of the insect (HABID; ANDRADE, 1998).

Similar to results of the present study, Brighenti et al. (2007) reported that adult workers of $A$. mellifera, fed with $B$. thuringiensis (commercial product Dipe ${ }^{\circledR} \mathrm{PM}$ - in the commercial concentration $0.5 \mathrm{~g}$ ), incorporated into the candy paste, after $96 \mathrm{~h}$ had a mortality of $57 \%$. In the first hours it was observed that the bees rejected the food, exhibiting a large loss of liquid feces caused by intestinal disorders, loss of agility, overnight isolation, and overall paralysis before death (BRIGHENTI et al., 2007).

The midgut cells of $A$. mellifera fed with candy paste containing different strains of Bt exhibited loss of destruction (arrow) (Figure 1) since the epithelial cells of the midgut of the bees resembled a crypt, were arranged concentrically, and located almost parallel to each other. The crypt and the epithelial cells feature a radial symmetry, and some cells are still not in contact with the lumen (RAES et al., 1994; CRUZ-LANDIM, 2009)

However, worker bees of A. mellifera ligustica and $A$. cerana cerana were not affected when they ingested Cry1Ah toxin (found in transgenic Bt corn) mixed in sugar syrup, and which did not interfere in the consumption of pollen and the mass of the hypopharingeal gland (DAI et al., 2011).

Although no apparent changes were observed in the bees, the Bt Cry spores can trigger physiological changes and differentially change enzymatic activities. This means that the apparent absence of toxicity may mask physiological disruptions that could be harmful to bees, especially in the case 
of exposure combined with other environmental stressors or high-dosages (RENZI et al., 2016).

A few minutes after ingestion of $B$. thuringiensis, histopathological changes begin to occur in the microvilli membranes of the midgut and, depending on the insect, extensive disintegration of the epithelial cells of the gut can occur in a few hours (HABID; ANDRADE, 1998) and, as described previously, these conditions can lead to the death of the insects.

The different strains of $B$. thuringiensis produce toxins and substances with specific actions. The most important of these toxins is $\delta$-endotoxin or crystal toxin, which initially targets the epithelium of the midgut, where toxins coming into contact with the epithelium cells cause an osmotic imbalance that leads to a break in feeding, and later causes an intestinal stop. Another toxin, $\beta$-exotoxin (thuringiensina) is fatal to insects and causes the death of species of Lepidoptera, Diptera, Coleoptera, Hymenoptera, Isoptera, and Orthoptera (HABID; ANDRADE, 1998).

It was observed that in the food bioassay, the three strains interfered with the longevity of the bees, probably because $B$. thuringiensis acts when it is ingested by insects, increasing mortality. However, as the farmers spray Bt products on the crops, field tests can be realized to assess the longevity of workers of $A$. mellifera and to analyse other environmental factors.

In fied conditions, the bees can come into contact with these products in three different ways in a single foraging: 1) being sprayed with the product, 2) coming into contact with sprayed plants, and 3) ingestion of the bacteria while gathering nectar and pollen. In the field, biotic factors (for example, predators and weeds) and abiotic factors (such as rain, wind, and temperature) interfere with bees coming into contact with the products, and can easily minimize the effects caused by applications of $B$. thuringiensis.

\section{Conclusions}

The three strains of $B$. thuringiensis (IPS 82, BR 81 , and BR 147) reduced the longevity of workers of the Africanized honey bee, A. mellifera, when added to candy paste and caused the disintegration of the epithelial cells of the mesenteron. The strains IPS 82 and BR 147 also reduced the longevity of worker bees in the bioassay of spraying $B$. thuringiensis on $A$. mellifera and in the bioassay of contact of $A$. mellifera with surface sprayed with $B$. thuringiensis, respectively.

\section{Acknowledgements}

We thank the Foundation for the Support of Scientific and Tecnological Development of Paraná (Araucaria Foundation) for provision of financial aid. We thank Prof. Dra. Gislayne F. L. T. VilasBôas (State University of Londrina) for providing the $B$. thuringiensis strains.

\section{References}

ANGELO, E. A.; VILAS-BÔAS, G. T.; CASTROGÓMEZ, R. J. H. Bacillus thuringiensis: características gerais e fermentação. Semina: Ciências Agrárias, Londrina, v. 31, n. 4, p. 945-958, 2010.

BAPTISTA, A. P. M.; CARVALHO, G. A.; CARVALHO, S. M.; CARVALHO, C. F.; BUENO FILHO, J. S. S. Toxicidade de produtos fitossanitários utilizados em citros para Apis mellifera. Ciência Rural, Santa Maria, v. 39, n. 4, p. 955-961, 2009.

BORTOLI, S. A. de; VACARI, A. M.; MAGALHÃES, G. O.; DIBELLI, W.; BORTOLI, C. P. de; ALVES, M. P. Subdosagens de Bacillus thuringiensis em Plutella xylostella (Lepidoptera: Plutellidae) e Trichogramma pretiosum (Hymenoptera: trichogrammatidae). Revista Caatinga, Mossoró, v. 25, n. 2, p. 50-57, 2012.

BRAVO, A.; LIKITVIVATANAVONG, S.; GILL, S. S.; SOBERÓN, M. Bacillus thuringiensis: A 383 story of a successful bioinsecticide. Insect Biochemistry and Molecular Biology, California, v. 41, n. 7, p. 423-431, 2011. 
BRIGHENTI, D. M.; CARVALHO, C. F.; CARVALHO, G. A.; BRIGHENTI, C. R. G.; CARVALHO, S. M. Bioatividade do Bacillus thuringiensis var. kurstaki (Berliner, 1915) para adultos de Apis mellifera Linnaeus, 1758 (Hymenoptera: Apidae). Ciência e Agrotecnologia, Lavras, v. 31, n. 2, p. 279-289, 2007.

CARVALHO, S. M.; CARVALHO, G. A.; CARVALHO, F. C.; BUENO FILHO, J. S. S.; BAPTISTA, A. P. M. Toxicidade de Acaricidas/Inseticidas empregados na Citricultura para a abelha africanizada Apis mellifera L., 1758 (Hymenoptera: Apidae). Arquivos do Instituto Biológico, São Paulo, v. 76, n. 4, p. 597-606, 2009.

COBRA, S. S. O.; SILVA, C. A.; KRAUSE, W.; DIAS, D. C.; KARSBURG, I. V.; MIRANDA, A. F. Características florais e polinizadores na qualidade de frutos de cultivares de maracujazeiro-azedo. Pesquisa Agropecuária Brasileira, Brasília, v. 50, n. 1, p. 54-62, 2015.

CRUZ-LANDIM, C. da. Abelhas: morfologia e função dos sistemas. São Paulo: UNESP, 2009. 408 p.

D'URSO, V.; MAZZEO, G.; VACCALLUZZO, V.; SABELLA, G.; BUCCHIERI, F.; VISCURO, R.; VITALE, D. G. M. Observations on midgut of Apis mellifera workers (Hymenoptera: Apoidea) under controlled acute exposures to a Bacillus thuringiensisbased biopesticide. Apidologie, Paris, v. 48, n. 1. p. 5162, 2017.

DAI, P. L.; ZHOU, W.; ZHANG, J.; JIANG, W. Y.; WANG, Q.; CUI, H. J.; SUN, J. H.; WU, Y. Y.; ZHOU, $\mathrm{T}$. The effects of Bt Cry1Ah toxin on worker honeybees (Apis mellifera ligustica and Apis cerana cerana). Apidologie, Paris, v. 43, n. 4, p. 384-391, 2011.

GALLO, D.; NAKANO, O.; SILVEIRA NETO, S.; CARVALHO, R.P.L.; BAPTISTA, C.G.; BERTI-FILHO, E.; OMOTO, C. Entomologia Agrícola, Piracicaba: FEALQ, 2002. 469 p.

HABID, M. E. M.; ANDRADE, C. F. S. Bactérias entomopatogênicas. In: ALVES, S. B. Controle microbiano de inseto. 2. ed. Piracicaba: FEALQ, 1998. p. 383-446.

LEZ, M. del M.; LLADO, G.; PETRO, A. B.; ALEMANY, A. First field assessment of Bacillus thuringiensis subsp. kurstaki aerial application on the colony performance of Apis mellifera L. (Hymenoptera: Apidae). Spanish Journal of Agricultural Research, Pakistan, v. 12, n. 2, p. 405-408, 2014.
MARINI, L.; TAMBURINI, G.; PETRUCCOTOFOLLO, E.; LINDSTRÖM, S. A. M.; ZANETTI, F.; MOSCA, G.; BOMMARCO, R. Crop management modifies the benefits of insect pollination in oilseed rape. Agriculture, Ecosystems \& Environment, Zurich, v. 207, n. 1, p. 61-66, 2015.

RAES, H.; VERBEKE, M.; MEULEMANSS, W.; OSTERS, W. de. Organisation and ultrastructure of the regenerative crypts in the of the adult worker honeybee Apis mellifera). Tissue and Cell, Siena, v. 26, n. 2, p. 231238, 1994.

RANGBERG, A.; DIEP, D. B.; RUDI, K.; AMDAM, G. V. Paratransgenesis: an approach to improve colony health and molecular insight in honey bees (Apis mellifera). Integrative and Comparative Biology, Florida, v. 52, n. 1, p. 89-99, 2012.

RENZI, M. T.; AMICHOT, M.; PAURON, D.; TCHAMITCHIAN, S.; BRUNET, J. L.; KRETZSCHMAR, A.; MAINI, S.; BELZUNCES, L. P. Chronic toxicity and physiological changes induced in the honey bee by the exposure to fipronil and Bacillus thuringiensis spores alone or combined. Ecotoxicology and Environmental Safety, New York, v. 127, n. 5, p. 205$213,2016$.

SILVA, D. M.; ANDRADE, A.; STECCA, C. dos S.; BUENO, A. de F.; NEVES, P. M. O. J.; MOSCARDI, F. Compatibilidade de entomopatógenos com Telenomus remus Nixon (Hymenoptera: Platygastridae). In: SIMPÓSIO DE CONTROLE BIOLÓGICO, SICONBIOL, 13., Bonito, 2013. Proceedings... Distrito Federal: Embrapa, 2013. p. 1.

SILVA, F. de A.; AZEVEDO, C. A. V. de. Versão do programa computacional Assistat para o sistema operacional Windows. Revista Brasileira de Produtos Agroindustriais, Bodocongó, v. 4, n. 1, p. 71-78, 2002.

STRAUB,L.; VILLAMAR-BOUZA,L.;BRUCKNER, S.; CHANTAWANNAKUL, P.; GAUTHIER, L.; KHONGPHINITBUNJONG, K.; RETSCHNIG, G.; WILLIAMS, G. R. Neonicotinoid insecticides can serve as inadvertent insect contraceptives. Proceedings of the Royal Society B: Biological Sciences, Londres, v. 283, n. 1835, p. 1-8, 2016.

TRIPLEHORN, C.A., JOHNSON, N.F. Estudo dos insetos: tradução da $7^{\text {a }}$ edição de Borror and Delong's introduction to the study of insects. São Paulo: Cengage Learning, 2011. 809 p.

VIUDA, M.; RUIZ, Y.; FERNÁNDEZ, J.;ALVAREZ, J. A. A. Functional properties of honey, propolis, and royal jelly. Journal of Food and Science, Medford, v. 73, n. 9, p. 117-124, 2008. 
